\title{
S-18-1 Zinc: Brain Maturation and Function
}

\author{
H.H.SANDSTEAD
}

Department of Preventive Medicine, University of Texas Medical Branch Galveston, Texas, 77550 USA

The report in 1920 of $40 \mathrm{mg}$ of zinc $(\mathrm{Zn}) / \mathrm{Kg}$ of brain tissue $[2,29]$ preceded description of the essentiality of $\mathrm{Zn}$ for animals [39] by 14 years. Histologic evidence of $\mathrm{Zn}$ in the mossy fiber system of the hippocampus [6] was reported in 1955 [23] as was naturally occurring $\mathrm{Zn}$ deficiency in swine [41]. Soon after, malformations of the brain were found in chicks from $\mathrm{Zn}$ deprived hens [1]. These findings were explained by the essentiality of $\mathrm{Zn}$ for synthesis of nucleic acids and proteins [20, 21, 42]. About the same time, findings in Egyptian and Iranian adolescents revealed $\mathrm{Zn}$ deficiency as the cause of growth stunting and delayed sexual maturation $[15,28,34]$. Later, severe $\mathrm{Zn}$ deprivation in rats was shown to impair thymidine incorporation into neural crest of embryos [38] and to cause teratology of the brain [18]. A related finding was suppression of thymidine incorporation into brain DNA of 10 day old suckling rats [33]. Estimates of $\mathrm{Zn}$ requirements and reported dietary intakes suggested that some pregnant women and infants were $\mathrm{Zn}$ deficient [30]. A subsequent study on Swedish women found $\mathrm{Zn}$ deficiency in pregnancy [19].

The above prompted us to study of $\mathrm{Zn}$ deficiency in rats during latter gestation, suckling and after weaning. Severe maternal $\mathrm{Zn}$ deprivation $(<1 \mathrm{mg}$ $\mathrm{Zn} \mathrm{/} \mathrm{Kg} \mathrm{diet)} \mathrm{from} \mathrm{the} \mathrm{14th} \mathrm{through} \mathrm{the} \mathrm{20th} \mathrm{day} \mathrm{of} \mathrm{gestation} \mathrm{caused} \mathrm{stunting,}$ and lower levels of DNA $(p<0.05)$ in brains of fetuses [24]. Nutritionally rehabilitated males displayed impaired $(p<0.01)$ avoidance of shock while litter mate females performed as well as the controls [14]. Rehabilitated females showed increased aggression in response to shock $(p<0.001)[10,13]$. The executive rat paradigm caused many gastric ulcers in the previously $\mathrm{Zn}$ deprived offspring [8].

Severe $\mathrm{Zn}$ deprivation from birth to weaning impaired acquisition of an elevated Tolman Honzig maze by adult offspring $(\mathrm{p}<0.01)$ [22]. Food motivation of the $\mathrm{Zn}$ deprived group was increased compared to ad libitum controls, but was less than that of food restricted controls [7]. Reference memory of shock applied on days $18,19,20$, or 21 of $\mathrm{Zn}$ deprivation was impaired $(\mathrm{p}<0.01)$ on the 40 th postnatal day [11]. Working memory of a 17 arm radial maze was also impaired $(\mathrm{p}<0.001)$ in adult offspring [9]. Histologic examination of the cerebellum on the $21 \mathrm{st}$ postnatal day found delayed maturation and little migration of external granular cell neurons [3, 4], grossly abnormal arborization of Purkinje Cell dendrites, and decreased numbers and abnormally shaped boutons [5].

Experiments were also done in mildly $\mathrm{Zn}$ deprived rats. The dams were fed $10 \mathrm{mg} \mathrm{Zn} / \mathrm{Kg}$ diet throughout pregnancy and lactation. Pair-fed or ad libitum-fed control dams were fed $25 \mathrm{mg} \mathrm{Zn} / \mathrm{Kg}$ diet. After weaning pups were fed a $\mathrm{Zn}$ adequate diet to 300 days of age. Working memory was measured using the 17 arm radial maze food reward paradigm [12]. Memory was impaired in the $\mathrm{Zn}$ deprived group ( $\mathrm{p}<0.001)$; the two control groups were 
similar. Histologic examination with toluidin blue of hippocampus of 300 day litter mates found dark staining granular cell neurons in the $\mathrm{Zn}$ deprived group $[17,47]$.

Zinc deprivation of weanling rats increased brain catecholamines [43], copper and manganese [45]. Zinc levels were not affected except in the olfactory bulb where they decreased. Zinc deprivation caused anorexia and cyclic feeding with food intake related to the level of plasma zinc but not to plasma amino acids, glucose, and fatty acids [44]. Brain tryptophane [46] and serotonin were increased [36]; tyrosine was marginally increased [46].

$\mathrm{Zn}$ deficiency in rhesus monkeys throughout most of the latter third of gestation impaired exploration and play during weaning of the infants $(p<0.01)$ [35]. Testing with complex learning sets found inferior performance at 300 and 700 days, but not at 1000 days [37].

In humans $\mathrm{Zn}$ deficiency causes congenital malformations, small baby size, maternal hypertension, and infant and maternal complications [31]. A recent study found a $>8 \mathrm{x}$ increased risk of fetal growth retardation among poor women with plasma $\mathrm{Zn}$ in the lowest quartile [26].

Little research has been reported on the effects of $\mathrm{Zn}$ deficiency on human brain. Evidence was reported in 1977 [16]. Zn deficiency was induced by large doses of histidine. Massive zincuria occurred and subjects showed ataxia, dysgeusia, dysosmia, nyctalopia, and disturbed mentation. $\mathrm{Zn}$ repletion restored function.

We induced mild $\mathrm{Zn}$ deficiency in 9 men [40]. Accuracy of backward recall of digits was inversely related to plasma $\mathrm{Zn}(\mathrm{n}=100, \mathrm{r}=-0.37, \mathrm{p}<0.001) ; \mathrm{Zn}$ retention was inversely related to accuracy $(n=94, r=-0.50, p<0.001)$ and speed $(\mathrm{n}=94, \mathrm{r}=-0.38, \mathrm{p}<0.001)$ of immediate recall of verbal and visual information. The latter findings disappeared when $\mathrm{Zn}$ nutriture was repleted.

Recently impaired neuropsychological function was reported in 14 men who were $\mathrm{Zn}$ depleted [27]. For 7 months the men were fed diets in random order that provided $1,2,3,4$, or 10 (control) $\mathrm{mg} \mathrm{Zn} /$ day for intervals of 35 days. Significant $(\mathrm{p}<0.05)$ decreases in function occurred in 2 sensory-motor tasks (pursuit and trials), 2 attention tasks (orienting and misdirection), 3 perceptual tasks (search, time estimate and Sternberg), 2 memory tasks (shape and cube recognition), and 1 spatial task (maze). Abnormalities were evident at all levels of $\mathrm{Zn}$ deprivation. The men also had impaired ethanol metabolism [25] but no decrease in plasma or WBC Zn (Milne, personal communication, 1991).

We [32] measured serum ferritin and plasma $\mathrm{Zn}$ in non-anemic premenopausal women, ages $19-40 \mathrm{y}$, and found lower mean plasma $\mathrm{Zn}$ $(\mathrm{p}<0.003)$ in women with serum ferritin $<20 \mathrm{mg} / \mathrm{L} \quad(n=32)$ compared to women with serum ferritin $>20 \mathrm{mg} / \mathrm{L}(\mathrm{n}=11)$.

The sideropenic women were enrolled in an 8 week double blind randomized controlled study of effects of $\mathrm{Fe}(30 \mathrm{mg})$ and/or $\mathrm{Zn}(30 \mathrm{mg})$, and/or a vitamin-mineral (VM) treatment on working memory (Wechsler Memory Scale No.1 \& 2 (WMS). Normal ferritin women were given VM. Tests of function were done on the 8 th day of the menstrual cycle.

The number of subjects in each treatment and \% change in the raw WMS scores are shown in Figure 1. The overall power was $90 \%$, assuming a $5 \%$ probability of a type I error and a $10 \%$ difference in test scores. The power of the findings in the sideropenic women given VM was $80 \%$.

$\mathrm{Fe}$ repletion of sideropenic subjects improved immediate recall of verbal material $21.2 \%$ after $\mathrm{Fe}(\mathrm{p}<0.009)$ and $18.7 \%$ after $\mathrm{Fe} \& \mathrm{Zn}(\mathrm{p}<0.098)$; in normal 
ferritin women VM was associated with a $26 \%$ increase $(p<0.001)$. Sideropenic women given $\mathrm{Zn}$, or only $\mathrm{VM}$ had no significant increase in score. However overall power was only $50 \%$, therefore negative findings must be interpreted with caution.

$\mathrm{Zn}$ and Fe improved short term memory of visual designs $17.9 \quad(\mathrm{p}<0.004)$ and $20 \% \quad(\mathrm{p}<0.03)$ respectively (Figure 2$)$. The overall power was $68 \%$. The power for the sideropenic VM group was $71 \%$. Only $\mathrm{Zn}$ improved immediate recall of word pairs. The change was $11.4 \%(\mathrm{p}<0.07)$. The power for the $\mathrm{Zn}$ group was $96 \%$, but for the sideropenic VM group was $34 \%$.

These findings, and those in men experimentally deprived of $\mathrm{Zn}$ indicate mild $\mathrm{Zn}$ deprivation can impair cognition of humans. Future research will show the significance of these findings for daily living.
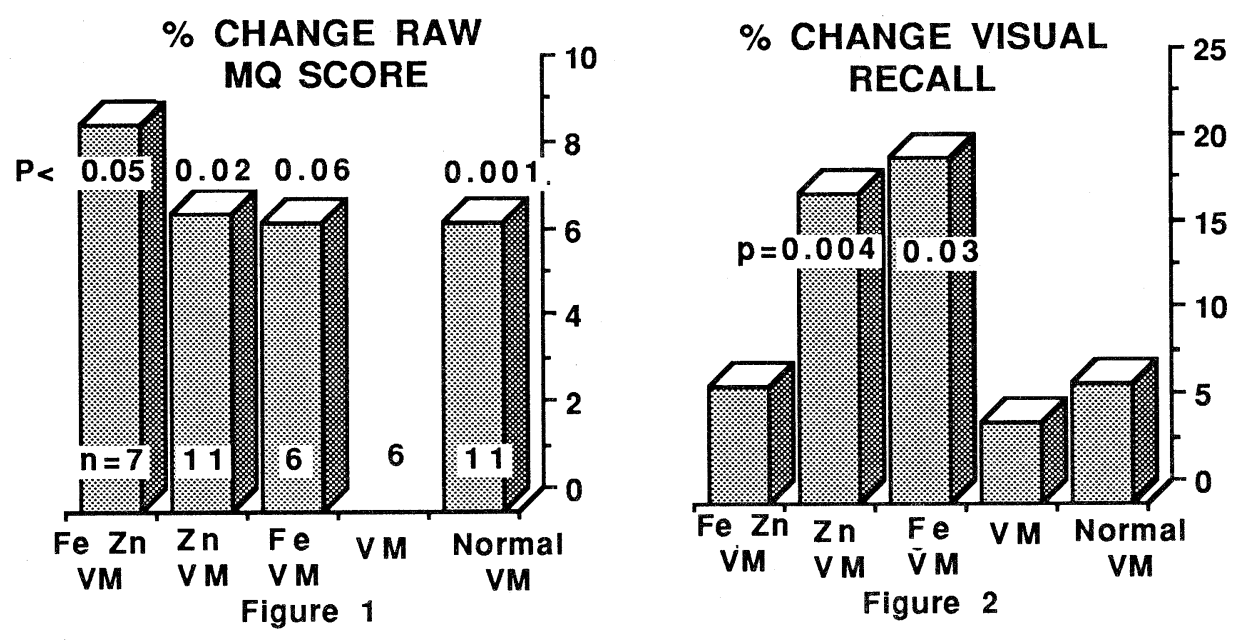

\section{ACKNOWLEDGEMENT}

I wish to express my gratitude to colleagues that have worked with me on the research noted above. Their contributions to the work have been invaluable.

\section{REFERENCES}

[1] Blamberg DL, Blackwood UB, Supplee WC, Combs GF. Proc Soc Exp Biol Med 1960;104:217.

[2] Bodansky M. J Biol Chem 1921;48:361.

[3] Buell SJ, Fosmire GJ, Ollerich DA, Sandstead HH. Exp Nuerol 1977;55:199.

[4] Dvergsten CL, Fosmire GJ, Ollerich DA, Sandstead HH. Brain Res 1983;271:217.

[5] Dvergsten CL, Fosmire GJ, Ollerich DA, Sandstead HH. Developmental Brain Res 1984; $16: 11$.

[6] Frederickson C. Neurobiology of zinc and zinc-containing neurons. In: Smythies J, Bradley $R$ ed. Internat Rev Neurobiol. New York: Academic Press, 1989: 145.

[7] Halas E, Burger P, Sandstead H. Animal Learning and Behavior 1980;8:152.

[8] Halas ES. Behavioral changes accompanying zinc deficiency in animals. In: Dreosti IE, Smith RM ed. Neurobiology of the Trace Elements, Vol. 1, Trace Element Neurobiology and Deficiencies. New Jersey: Humana Press, 1983: 213.

[9] Halas ES, Eberhardt MJ, Diers MA, Sandstead HH. Physiol Behav 1983;30:371.

[10] Halas ES, Hanlon MJ, Sandstead HH. Nature 1975;257:221.

[11] Halas ES, Heinrich MD, Sandstead HH. Physiol Behav 1979;22:991.

[12] Halas ES, Hunt CD, Eberhardt MJ. Physiol Behav 1986;37:451.

[13] Halas ES, Reynolds GM, Sandstead HH. Physiol Behav 1977;19:653. 
[14] Halas ES, Rowe MC, Johnson OR, et al. Effects of intrauterine zinc deficiency on subsequent behavior. In: Prasad AS ed. Trace Elements in Human Health and Disease. New York: Academic Press, 1976: 327.

[15] Halsted JA, Ronaghy HA, Abadi P, et al. Am J Med 1972;53:277.

[16] Henkin RI, Patten BM, Re PK, Bronzert DA. Arch Neurol 1975;32:745.

[17] Hunt C, Halas E, Sandstead H. Fed Proc 1984;43:382A.

[18] Hurley LS, Swenerton H. Proc Soc Exp Biol Med 1966;123:692.

[19] Jameson S. Acta Med Scand Suppl 1976;593:4.

[20] Lieberman I, Ove P. J Biol Chem 1962;237:1634.

[21] Lieberman L, Abrams R, Hunt N, Ove P. J Biol Chem 1963;238:3955.

[22] Lokken PM, Halas ES, Sandstead HH. Proc Soc Exp Biol Med 1973;144:680.

[23] Maske H. Naturewissenschaften 1955;42:424.

[24] McKenzie JM, Fosmire GJ, Sandstead HH. J Nutr 1975;105:1466.

[25] Milne DB, Johnson PE, Gallagher SK. Am J Clin Nutr 1991;53:P25.

[26] Neggers YH, Cutter GR, Acton RT, et al. Am J Clin Nutr 1990;51:678.

[27] Penland JG. FASEB J 1991;5:A938.

[28] Prasad AS, Miale A. J, Farid Z, et al. J Lab Clin Med 1963;61:537.

[29] Rost E. Umschau 1920;24:201.

[30] Sandstead HH. Am J Clin Nutr 1973;26:1251.

[31] Sandstead HH. Arch Pediatr 1991;(In Press)

[32] Sandstead HH, Darnell LS, Alcock NW. FASEB J 1991;5:A1291.

[33] Sandstead HH, Gillespie DD. Pediatr Res 1972;6:119.

[34] Sandstead HH, Prasad AS, Schulert AR, et al. Am J Clin Nutr 1967;20:422.

[35] Sandstead HH, Strobel DA, Logan GM Jr., et al. Am J Clin Nutr 1978;31:844.

[36] Sandstead HH, Wallwork JC, Halas ES, et al. Zinc and central nervous function. In: Sarkar B ed. Biological Aspects of Metals and Metal Related Diseases. New York: Raven Press, 1983: 225.

[37] Strobel DA, Sandstead HH. Social and learning changes following prenatal or postnatal zinc deprivation in rhesus monkeys. In: Frederickson CJ, Howell GA, Kasarskis EJ ed. The Neurobiology of Zinc. Part BL Deficiency, Toxicity, and Pathology. New York: Alan R. Liss, Inc., 1984: 121.

[38] Swenerton H, Shrader R, Hurley L. Science 1969;166:1014.

[39] Todd WR, Elvehjem CA, Hart EB. Am J Physiol 1934;107:146.

[40] Tucker DM, Sandstead HH. Neuropsychological function in experimental zinc deficiency in humans. In: Frederickson CJ, Howell GA, Kasarskis EF ed. The Neurobiology of Zinc. Part B: Deficiency, Toxicity, and Pathology. New York: Alan R. Liss, Inc., 1984: 139.

[41] Tucker HF, Salmon WD. Proc Soc Exp Biol Med 1955;88:613.

[42] Wacker W. Biochemistry 1962;1:859.

[43] Wallwork JC, Botnen JH, Sandstead HH. J Nutr 1982;112:514.

[44] Wallwork JC, Fosmire GJ, Sandstead HH. Br J Nutr 1981;45:127.

[45] Wallwork JC, Milne DB, Sims RL, Sandstead HH. J Nutr 1983;113:1895.

[46] Wallwork JC, Sandstead HH. J Nutr 1983;113:47.

[47] Wallwork JC, Sandstead HH. Zinc and brain function. In: Prasad AS ed. Trace Elements. New York: Alan R. Liss, Inc., 1991: in press. 